\title{
Hazard Analysis Critical Control Points (HACCP) - Principle 3: Establish Critical Limits and Principle 4: Monitoring Critical Control Points (CCPs) 1
}

Ronald H. Schmidt and Debby L. Newslow ${ }^{2}$

\section{Critical Limits}

\section{A. Definition of Critical Limits}

For every Critical Control Point (CCP) identified, there must be a Critical Limit (CL), or a parameter to indicate whether or not the control measure is, in fact, controlling the identified hazards. The definition of CLs by different organizations or agencies is shown in Table 1. With the exception of the FSIS definition, which is more prescriptive in nature, these definitions are pretty similar. Failure to meet a CL is defined as a deviation. If a deviation occurs, food products being produced are unsafe or potentially unsafe (using the definitions you used when you set the CCPs and CLs).

\section{B. Determining Critical Limits (CLs)}

The underlying principles in determining CLs are that preventative or control measures are needed to assure compliance with a CL, and that every identified significant hazard at a CCP must be controlled. Therefore, CLs must be accurate, precise, and based upon current scientific information. In addition, they must be realistic, reasonable, and achievable. They must also be measurable (or easily monitored) in real time, and able to be verified.

The HACCP team should ask the following questions:

- How are CLs identified?

- What are the appropriate and reasonable parameters or boundaries for food safety?

- What is the method that will be applied to determine the magnitude of each parameter?

- What are the measurable criteria?

\section{Components of Critical Limits}

A CL may be a single parameter or a combination of multiple parameters. Further, there may be both primary and secondary components of CLs. The primary component is the parameter which is monitored in the HACCP system, while other factors which may be important to the operation. For example, in heating food products, the primary $\mathrm{CL}$

1. This document is FSHN 07-05, one of a series of the Department of Food Science and Human Nutrition, Florida Cooperative Extension Service, IFAS, University of Florida. First published July 2007. Please visit the EDIS Web site at http://edis.ifas.ufl.edu.

2. Ronald H. Schmidt, professor, Food Science and Human Nutrition Department, Cooperative Extension Service, Institute of Food and Agricultural Sciences, University of Florida, Gainesville FL 32611, and Debby Newslow, Executive Director, D.L. Newslow and Associates, Inc.

The Institute of Food and Agricultural Sciences (IFAS) is an Equal Opportunity Institution authorized to provide research, educational information and other services only to individuals and institutions that function with non-discrimination with respect to race, creed, color, religion, age, disability, sex, sexual orientation, marital status, national origin, political opinions or affiliations. U.S. Department of Agriculture, Cooperative Extension Service, University of Florida, IFAS, Florida A. \& M. University Cooperative Extension Program, and Boards of County Commissioners Cooperating. Larry Arrington, Dean 
may be the processing temperature and the processing time. However, in situations where processing time is preset and cannot be varied, the primary CL (or the one that is monitored) may only be the process temperature. Other secondary factors important to the thermal inactivation of pathogens must also be considered (e.g., fill weight, compositional factors, other factors). These secondary factors may be managed through prerequisite programs.

\section{Operating Limits (OLs)}

It is usually recommended that operating limits (OLs) be established. These OLs are more stringent than CLs and allow a safety margin. Thus, adjustments to the process may be made, avoiding a deviation from a CL and the production of a potentially unsafe food product.

\section{Monitoring CCPs}

\section{A. Definition of HACCP Monitoring}

Monitoring procedures are developed to determine whether the CLs are being met. These procedures provide documentation (records) proving that the HACCP system is operating in accordance with the plan and is controlling hazards as required by defined parameters. Definitions for monitoring by different agencies and organizations are presented in Table 2. The common thread among these definitions is that monitoring is a planned, scheduled sequence of measurements to assure that the CCP is under control.

\section{B. General Considerations in Monitoring}

In general, the purpose of monitoring is to:

- track the HACCP system's operation;

- identify and determine loss of control and deviation at a CCP (exceeding the CL); and

- provide written documentation of the process.

The questions to be asked by the HACCP team are as follows:

- What will be monitored? The HACCP team must determine what parameters shall be monitored and what other specific information and data analysis are required to adequately measure compliance with the CL.
- How will it be monitored? The HACCP team must determine what methods will be used and assess their reliability. In addition, the team must determine what records will be required in order to demonstrate compliance with defined requirements.

- When will it be monitored? The HACCP team must determine whether monitoring will be continuous, noncontinuous, or intermittent, and must determine the appropriate monitoring frequency.

- Where will monitoring be done? The HACCP team must determine the precise points within the food system for monitoring data collection.

- Who will perform the monitoring? The HACCP team must identify the person(s) responsible for monitoring and assess the training needs for the responsible person(s). In addition, the role of the supervisor must be identified, and procedures must be established for both the responsible person(s) and the supervisors signing or initialing the monitoring forms.

\section{Characteristics of Monitoring Methods}

HACCP monitoring techniques must be reliable and statistically sound, providing adequate precision and accuracy. Therefore, objective methods are often preferred over subjective methods. Instrumental detection is also preferred over visual observations. However, there are many cases where visual observations are used (e.g., employee monitoring and recording of temperature).

HACCP monitoring must provide real-time data. For example, while scientifically sound methods of product testing for chemical or microbial hazards are available, such tests would not be appropriate in HACCP monitoring because of the time lag (often days) before results are obtained. The use of screening test kits, however, may be appropriate (provided they are calibrated appropriately), as results become available immediately.

Monitoring procedures must be compatible with Principle 7 - Recordkeeping. Monitoring procedures provide an accurate record of CCPs and their control. 
This includes providing information regarding trends in the process.

\section{Critical Limit and Monitoring Scenarios}

Some examples of CLs and their monitoring are discussed below:

\section{A. Low-Acid Canned Foods}

- Hazard: Biological (Clostridium botulinum)

- Control Measure: Thermal inactivation

- CCP: Retort Processor

In this situation, the CLs are processing temperature and processing time to achieve sterilization through a process which has been certified under FDA low-acid canned food regulations. In this case, monitoring is continuous (through a continuous recording device). Other secondary factors (described above) would be controlled by prerequisite programs.

\section{B. Pasteurized Milk}

- Hazard: Biological (enteric pathogens, listed specifically)

- Control Measure: Thermal inactivation

- CCP: High Temperature Short Time (HTST) Pasteurizer

The $\mathrm{CL}$ for milk pasteurization is $161^{\circ} \mathrm{F}$ for 15 seconds, as defined under the Grade A Pasteurized Milk Ordinance regulations. In those situations where process time is controlled by a positive displacement pump that has been sealed as per regulations, it is appropriate to simply identify the temperature $\left(161^{\circ}\right.$ $\mathrm{F}$ ), which is monitored by continuous recorder, as the CL. However, in situations where the flow is not preset and sealed by a regulatory authority (e.g., milk pasteurized using magnetic flow meter systems; juice and beverage pasteurizers), the time must also be monitored as a CL. In addition, secondary components (e.g., flow diversion valve operation, pressure differentials between the plates in the regenerator and cooling section) should be controlled and managed by prerequisite programs.

\section{Cheddar Cheese}

- Hazard: Biological (Staphylococcus aureus: enterotoxin)

- Control Measure: Inhibition by lactic acid

- CCP: Fermentation step

In this scenario, warm temperatures are required for the growth of the lactic acid starter microorganisms. However, should the starter culture not grow sufficiently to produce the appropriate level of lactic acid, pathogens could grow during the fermentation stage. Because of its salt tolerance, Staphylococcus aureus is the pathogen of most concern, should it grow and produce an enterotoxin. Thus, the CL in this situation is not temperature nor time, but rather, the amount of acid development over time. The HACCP team has several choices in implementing the HACCP system. They could monitor either $\mathrm{pH}$ or titratable acidity (TA) at defined time intervals (or continuously), or simply measure the $\mathrm{pH}$ or TA after a selected time period. Other secondary factors (e.g., starter culture handling practices, prevention of antibiotic inhibitors, others) would be controlled by prerequisite programs.

\section{Ground Beef}

- Hazard: Metal fragments

- Control Measure: Automatic rejection of packaging containing metal fragments of sufficient size to be detected by a metal detection system

- CCP: Metal detector

The CL in this case is open to some discussion. In many HACCP plans (including those under federal regulation), the $\mathrm{CL}$ is defined as the rejection size of the metal detector, and monitoring is continuous by the detector itself. Others may prefer to have an employee monitor the detector on a defined frequency to determine its operation. In this case, it may be more appropriate to indicate that the CL is simply whether the detector is operating (on vs. off), rather than the size exclusion limit of the detector. In both cases, the detector is calibrated as part of HACCP verification. 


\section{E. Sanitizing Fresh Produce}

- Hazard: Biological (pathogens listed specifically)

- Control Measure: Inactivation using chemical sanitizer

- CCP: Produce sanitizing spray unit

Inactivation of pathogens requires an appropriate concentration and contact time with an approved chemical sanitizing solution under appropriate conditions. Thus, the CLs in this situation would be both concentration and contact time. However, in systems where time is accurately controlled by the conveyor speed, it may be appropriate to identify the $\mathrm{CL}$ as concentration. As the activity of a chemical sanitizer is dependent upon compositional and other factors (e.g., temperature, $\mathrm{pH}$ ), there are also secondary factors which may be controlled using prerequisite programs. With regard to monitoring, there are several options. The most commonly used technique is to monitor the level of the sanitizer delivered at the spray head using a reliable test kit. This is usually done manually by an operator at a predefined frequency. In more automated systems, it may be desirable to monitor the speed of sanitizer addition (e.g., pump speed).

\section{Recording Critical Limits and Monitoring Procedures}

The HACCP Plan Form (Table 3) provides a thumbnail summary of the HACCP plan. CLs and monitoring procedures (including what, how, when, where and who) are concisely recorded on the form. Only the primary CLs are listed on the form. Secondary factors and Operating Limits should not be placed on the form, but may be discussed in a narrative in the HACCP plan.

\section{Summary}

The HACCP plan is dependant upon clearly defined, reliable CLs and monitoring techniques for each CCP. All employees involved with the HACCP plan must be fully aware of the identification, definition, and importance of CLs and associated monitoring procedures.

\section{References}

Codex Alimentarius. (2003). Hazard analysis and critical control point (HACCP) system and guidelines for its application. ANNEX to Recommended International Code of Practice/General Principles of Food Hygiene. CAC/RCP 1-1969, Rev 4. FAO/WHO Codex Alimentarius Commission.

National Advisory Committee on Microbiological Criteria for Foods (NACMCF). (1998). Hazard analysis and critical control point principles and application guidelines. Journal of Food Protection, 61, 762.

Food and Drug Administration Center for Food Safety and Applied Nutrition. (1995). Procedures for the safety and sanitary processing and importing of fish and fishery products. Final Rule, 18 Dec. 1995. Federal Register, 60, 65095-65202.

Food and Drug Administration Center for Food Safety and Applied Nutrition. (1995). Fish and fishery products. Code of Federal Regulations, Title 21, Part 123.

Food and Drug Administration Center for Food Safety and Applied Nutrition. (2001). Hazard analysis and critical control point (HAACP) (sic) procedures for the safe and sanitary processing and importing of juice. Final Rule, 19 Jan. 2001. Federal Register, 66, 6137-6202.

Food and Drug Administration Center for Food Safety and Applied Nutrition. (2001). Hazard analysis and critical control point (HACCP) systems. Code of Federal Regulations, Title 21, Part 120.

Food Safety and Inspection Service. (1996). Pathogen reduction; hazard analysis and critical control point (HACCP) systems. Final Rule, 25 July 1996. Federal Register, 61, 38856-38906.

Food Safety and Inspection Service. (1996). Hazard analysis and critical control point (HACCP) systems. Code of Federal Regulations, Title 9, Part 417. 
Scott, V. N., and Stevenson, K. E. (2006). HACCP: A

systematic approach to food safety. Washington,

D.C.: Food Products Association.

Schmidt, R. H., and Newslow, D. L. (2007).

Hazard analysis critical control points (HACCP) -

Getting started, preliminary steps (FSHN0701).

Gainesville: Department of Food Science and

Human Nutrition, Florida Cooperative Extension

Service, Institute of Food and Agricultural Sciences, University of Florida. Retrieved July 24, 2007, from http://edis.ifas.ufl.edu/FS137

Schmidt, R. H., and Newslow, D. L. (2007).

Hazard analysis critical control points (HACCP) Prerequisite programs (FSHN0702). Gainesville:

Department of Food Science and Human

Nutrition, Florida Cooperative Extension Service, Institute of Food and Agricultural Sciences, University of Florida. Retrieved July 24, 2007 from http://edis.ifas.ufl.edu/FS138

Schmidt, R. H., and Newslow, D. L. (2007).

Hazard analysis critical control points (HACCP) Principle 1: Conduct a Hazard Analysis

(FSHN0703). Gainesville: Department of Food

Science and Human Nutrition, Florida

Cooperative Extension Service, Institute of Food and Agricultural Sciences, University of Florida.

Retrieved August 1, 2007, from

http://edis.ifas.ufl.edu/FS139

Schmidt, R. H., and Newslow, D. L. (2007).

Hazard analysis critical control points (HACCP) -

Principle 2: Determine Critical Control Points

(CCPs) (FSHN0704). Gainesville: Department of

Food Science and Human Nutrition, Florida

Cooperative Extension Service, Institute of Food and

Agricultural Sciences, University of Florida.

Retrieved August 1, 2007, from

http://edis.ifas.ufl.edu/FS140 
Table 1. Definition of Critical Limit (CL)

\begin{tabular}{||l|l||}
\hline \multicolumn{1}{|c|}{ Organization or Agency } & \multicolumn{1}{c|}{ Critical Limit (CL) Definition } \\
\hline $\begin{array}{l}\text { National Advisory Committee on Microbiological } \\
\text { Criteria for Foods (NACMCF) }\end{array}$ & $\begin{array}{l}\text { One (or more) prescribed tolerances that must be met to ensure } \\
\text { that the CCP effectively controls the biological, chemical or } \\
\text { physical hazard }\end{array}$ \\
\hline Food and Drug Administration (FDA) & $\begin{array}{l}\text { A maximum or minimum value to which a biological, chemical, or } \\
\text { physical parameter must be controlled at a CCP to prevent, } \\
\text { eliminate, or reduce (to an acceptable level) the occurrence of the } \\
\text { identified food safety hazard }\end{array}$ \\
\hline $\begin{array}{l}\text { USDA/Food Safety and Inspection Service } \\
\text { (FSIS) }\end{array}$ & $\begin{array}{l}\text { CLs shall, at a minimum, be designed to ensure that applicable } \\
\text { targets or performance standards established by FSIS, and any } \\
\text { other requirements set forth, are met. }\end{array}$ \\
\hline Codex Alimentarius & A criterion which separates acceptability from unacceptability \\
\hline \hline
\end{tabular}

Table 2. Monitoring Definitions

\begin{tabular}{||l|l||}
\hline \hline \multicolumn{1}{|c||}{ Agency or Organization } & \multicolumn{1}{c|}{ Monitoring Definition } \\
\hline NACMCF & $\begin{array}{l}\text { A planned sequence of observations of critical limits designed to } \\
\text { produce an accurate record and intended to ensure that the critical limit } \\
\text { maintains product safety. }\end{array}$ \\
\hline FDA & $\begin{array}{l}\text { The scheduled testing or observation of the effectiveness of a process } \\
\text { to control CCPs and their limits. }\end{array}$ \\
\hline USDA/FSIS & $\begin{array}{l}\text { Procedures, and the frequency with which these will be performed, that } \\
\text { will be used to monitor each of the CCPs to ensure compliance with the } \\
\text { CLs. }\end{array}$ \\
\hline Codex Alimentarius & $\begin{array}{l}\text { The act of conducting a planned sequence of observations or } \\
\text { measurements of control parameters to assess whether a CCP is under } \\
\text { control. }\end{array}$ \\
\hline \hline
\end{tabular}




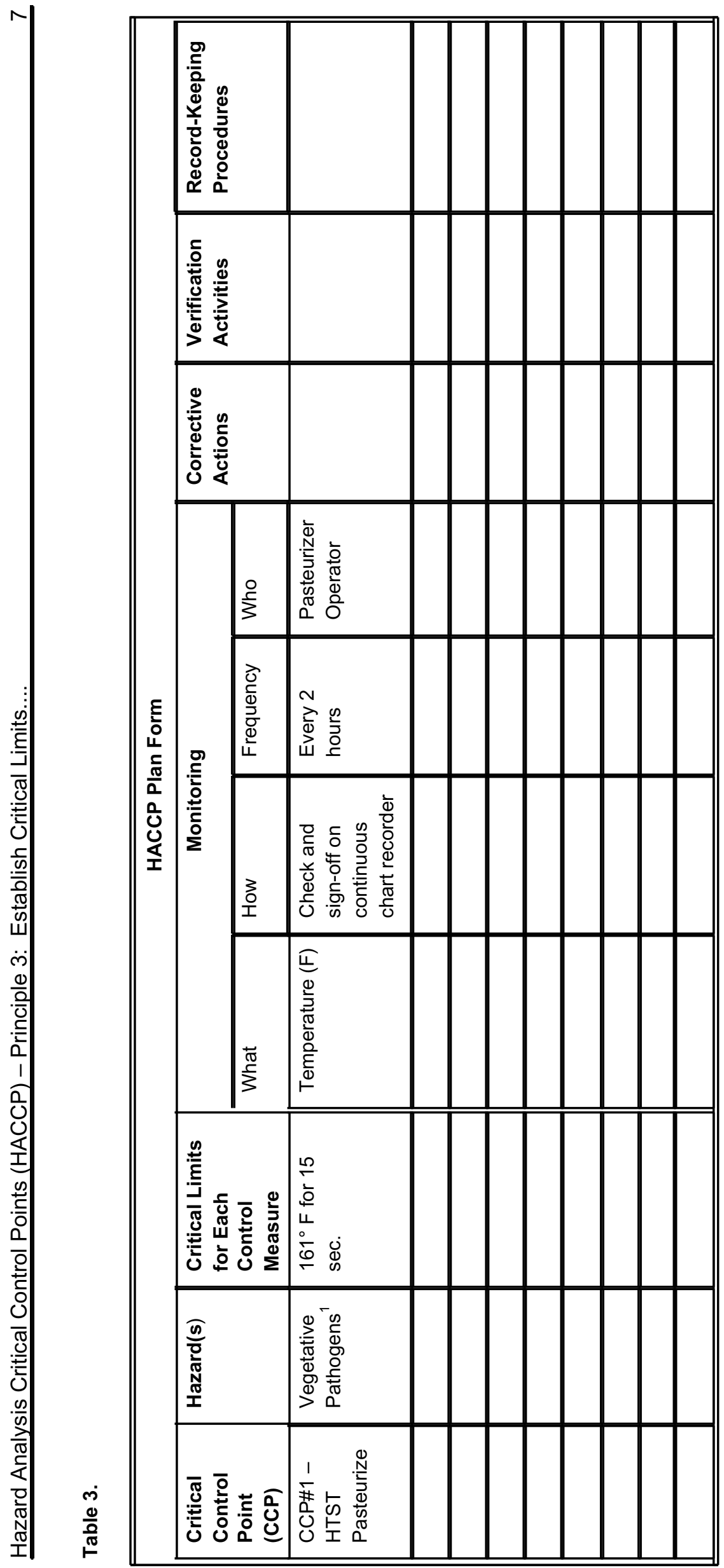

